\title{
Acquired Goodwill and Residual Income Components: A Study on the French Market
}

\author{
Denis Cormier*1 and Côme Segretain ${ }^{2}$ \\ ${ }^{1}$ ESG UQAM, Canada \\ ${ }^{2}$ IAE de Lille, LEM, France
}

Submission: May 13, 2019; Published: June 07, 2019

"Corresponding author: Denis Cormier, ESG UQAM, P.O. Box 8888, downtown station Montréal, Québec, Canada

\begin{abstract}
To address the question as to whether accounting for goodwill in International Financial Reporting Standards is appropriate, we investigate whether the acquired goodwill of a company is generating future residual earnings. In this paper, we investigate whether the acquired goodwill is generating future results in two components: net and additional income (i.e. other comprehensive income). To do this, we decompose the goodwill as Johnson \& Petrone [1]. and formalize, based on the residual income valuation model [2], a link between acquired goodwill, comprehensive residual income generated by these acquisitions and the premium paid. Results based on regressions conducted on French companies constituting the SBF 120 show a significant association between acquired goodwill and subsequent residual income of acquiring firms, and on the two components of income (net income and other comprehensive income).
\end{abstract}

Keywords: Goodwill; Residual Income; Ohlson's Model; Comprehensive Income

\section{Introduction}

The goodwill is the discounted sum of future residual income, i.e. earnings beyond the "normal" return on capital and called abnormal or extraordinary earnings [2]. Under IFRS 3 Business combinations, goodwill arising in a business combination represents a payment made by the acquirer in anticipation of future economic benefits from assets that cannot be separately identified and recognized. Only acquired goodwill is accounted for under IFRS. Internally generated goodwill is not recognized as an asset because it is not an identifiable resource controlled by the entity that can be measured reliably at cost. The rules applicable to the recognition of goodwill in the consolidated accounts of French firms were largely modified by the adoption of IFRS on 2005. Hence, with the removal of systematic depreciation of goodwill and its replacement with impairment testing, return on equity of listed companies instantly increase.

This study focuses on French firms composing the SBF 120 (Société des bourses françaises). It seeks to establish the extent to which goodwill in a given period generates consecutive residual income, according to two components: net income and other comprehensive income - OCI. Moreover, confirming the link between the acquired goodwill and subsequent residual income pave the way for empirical research highlighting the periods or areas where goodwill is justified or otherwise where the price premium is obvious.
Future residual income of the target firm and synergies are the heart of goodwill (core goodwill) and are the only elements that deserve to be capitalized as goodwill. Henning et al. [3]. show a positive and statistically significant association between stock returns and these components, with a greater weight for synergies. However, the premium paid would be negatively valued by the stock markets, seen as an additional cost of the combination.

\section{Goodwill and Future Residual Income}

It is known at least since Preinreich [4] that it is possible to assess the market value of equity of a firm from its shareholders' equity and the sum of its residual abnormal or future earnings; the discounted sum of the latter constituting the economic goodwill. This relation is formalized in the Residual Income Valuation model [2,5] obtained using the residual income defined from clean surplus relation (i.e. comprehensive income). Since, there has been debate as to whether transitory or unrealised items constituting OCI are relevant $[6,7]$.

Let's decompose the price paid for the acquisition of firm i at time $t$ as the market value of equity $p_{i, t}$ over $S_{y n}$ the present value of expected synergies from the transaction plus a premium $\mathrm{SP}_{\mathrm{i}}$ linked to hubris' leaders, at a pricing error, at market conditions, negotiating conditions or strategic premium. Starting with residual income valuation: 
(1) $p_{t=} b v_{t}+\sum_{n=1}^{\infty} E\left(x_{t+n}^{a}\right)$ (Residual Income Valuation)

$\mathrm{p}=$ Market price, $\mathrm{bv}=$ book value of equity, $\mathrm{x}^{\mathrm{a}}=$ Residual income

(2) Price paid $_{i . t}=p_{i . t}+S_{\text {SN }}+$ SP $_{i}$ where SYN $=$ Synergy, SP = Stock premium

$\mathrm{p}_{\mathrm{i} . \mathrm{t}}$ is replaced in (2) by expression in (1):

(2bis) Price paid $_{i . t}=b v_{i . t}+E\left(x_{i . t+n}^{a}\right) \cdot R_{i}^{-n}+S Y N_{i}+S P_{i}$ , with $\mathrm{R}=1+\mathrm{r}$

Then replace Price paid ${ }_{i . t}$ in the definition of goodwill (3):

(3) Goodwill $_{\mathrm{i} . \mathrm{t}}=$ Price paid $_{\mathrm{i} . \mathrm{t}}-\mathrm{FVE}_{\mathrm{i} . \mathrm{t}}$ where FVE $=$ Fair value of equity

Upon acquisition, FVE $=$ bv

The goodwill recorded for firm ${ }_{i}$ in $_{t}$ is equal to the price paid, less the fair value of its equity (FVE).

(3bis) Goodwill $l_{i . t}=\sum_{n=1}^{\infty} E\left(x_{i . t+n}^{a}\right) \cdot R_{i}^{-n}+S Y N_{i}+S P_{i}$

\section{Empirical Model}

At the acquiror level, successive acquisitions generate in times goodwill, and hopefully residual income and synergies, i.e. residual income for the buyer. We separate residual income into two components, and control for market value and P/E.

Goodwill $_{i . t}=\alpha_{1} x^{*}{ }_{i . t+1}+\alpha_{2}\left(x_{i . t+1}^{a}-x_{i . t+1}^{*}\right)+\alpha_{2} M V_{i . t}+\alpha_{3} P / E_{t}+\beta_{i . t}+\varepsilon_{i . t}$

With $: x_{i, t+1}^{a}$ : Residual comprehensive income $\left(x_{n}^{a}=\right.$ Comprehensive income $e_{n}-$ Equity $\left._{n-1} \cdot r_{n}\right)$;

$x_{i . t+1}^{*}$ : Residual net income $\left(x_{n}^{*}=\right.$ Net income $_{n}-$ Equity $\left._{n-1} . r_{n}\right) ; M V_{i \cdot t}$ : Market value of equity. These variables are scaled by equity book value in year t. $\mathrm{P} / \mathrm{E}_{\mathrm{t}}$ : Median Price-Earnings ratio in year $\mathrm{t}$.

Comprehensive income (CI) is computed as the variation of equity net of transactions with shareholders. Items are: Ordinary Share Capital, Preference Capital Reserves, Equity Issued and Dividends Paid [8].

$$
C I_{n}=\Delta O S C_{n}+\Delta P C_{n}+\Delta R_{n}-E I_{n}+D P_{n}
$$

The cost of equity $r_{n}$ is computed by applying the CAPM as the sum of risk-free rate (annual) and the product of an equity risk premium (fixed) by beta (annual). The financial data - Treasury bond rate (OAT 5 years) and betas were also collected annually on Datastream. The equity risk premium has been fixed at $4 \%$. Goodwill and total intangible assets are collected from annual reports.

An implicit assumption is that the subsequent residual income is representative of all earnings generated by an acquisition in the medium to long-term. Statistically, this assumption is realistic for a large sample, although at the firm level, we can always highlight growth patterns of nonlinear earnings. In addition, this point is in line with the assumption of autoregressive process or persistence of residual income of Ohlson's model.
We can capture the series of all residual income through market capitalization divided by shareholders' equity. Dividing the terms of the residual income valuation (RIV) by book value of equity, the Market-to-Book ratio then appears to be equal to 1 plus the sum of future earnings anticipated by the market and divided by equity. The Market-to-Book ratio captures earnings generated over a long period, including goodwill and other capitalized intangible assets. By using the Market-to-Book ratio as the dependent variable, Cazavan-Jeny [9] had already highlighted on pre-IFRS French data the significant association of goodwill divided by total assets. The integration in the regression of Market-to-Book is in line with the assumption of autoregressive process or persistence of residual income. It is expected that the market to book ratio is strongly correlated with the residual outcome measures, generating multicollinearity.

Concerning the proxy for stock premium, we use the median ratio on the sample Price-Earnings ratio. As in Gu \& Lev [10], P/E captures for each year fluctuations in the equity markets affecting the price of acquisitions. We must also keep in mind that the value relevance studies show a positive association between goodwill per share and stock price.

\section{Sample Selection}

This study focuses on 71 non-financial firms listed in the French market index SBF 120 for years 2005 and 2008, representing a sample of 284 firms-years. The sample starts from 111 nonfinancial firms from which we remove 11 firms with no goodwill or negative equity. From this sample of 100 firms, we focus on observations presenting high external growth as expressed by a ratio of Goodwill/Total intangible assets larger than 50\%.

Results

Table1: $\quad x_{i, t+1}^{*}: \quad$ Residual net income $x_{n}^{*}=$ Net income $_{n}-$ Equity $\left._{n-1} . r_{n}\right) ; x^{a}{ }_{i . t+1}$ : Residual comprehensive income $\left(x^{a}{ }_{n}=\right.$ Comprehensive income $_{n}-$ Equity $\left._{n-1} \cdot r_{n}\right) ; M V_{i^{\prime} t}$ : Market value of equity; TIA: Total intangible assetsn. These variables are scaled by equity book value in t. P/Et: Median Price-Earnings ratio in t.

\begin{tabular}{|c|c|c|c|c|}
\hline & Min. & Max. & Mean & Std Dev. \\
\hline Goodwill $_{n}$ & 0 & 51.98 & 0.69 & 2.49 \\
\hline $\mathbf{x}_{n+1}^{*}$ & -2.23 & 5.68 & 0.06 & 0.39 \\
\hline$x_{n+1}^{a} \cdot x_{n+1}^{*}$ & -2.26 & 2.63 & 0.04 & 0.41 \\
\hline $\mathbf{x}_{n+1}^{\mathrm{a}}$ & -2.31 & 8.31 & 0.1 & 0.61 \\
\hline $\mathbf{M V}_{\mathrm{n}}$ & 0.09 & 89.75 & 2.71 & 4.87 \\
\hline$P / E_{n}$ & 10.7 & 19 & 15.58 & 3.05 \\
\hline TIA $_{n}$ & 0 & 69.81 & 1.06 & 3.42 \\
\hline
\end{tabular}

(Table 1) presents descriptive statistics to all the variables. Other comprehensive residual income component on average represents $4 \%$ of equity against $6 \%$ for net residual income component. Goodwill and total intangible assets represent on average $69 \%$ and $106 \%$ of equity respectively. 
(Table 2) reports results of hierarchical regressions on the determinants of goodwill. Since we use panel data to estimate our models, the problem of heteroscedasticity and autocorrelation might be an issue. The test of Breusch-Pagan/Cook-Weisberg shows the presence of heteroscedasticity. Thus, the structure of errors among the panels is presumed to be heteroscedastic. To this end, we estimate regressions by the method of feasible generalized least squares (FGLS) with random effects (based on Hausman test). To overcome the problems of stability of regressions that generates the correlation between residual income and Marketto-Book, we use the natural logarithm of the Market-to-Book ratio. Results are the following. First, the successive introduction of variables is done without disruption of coefficients and progression of Wald test for each coefficient introduced. We observe that future residual net income has a larger influence on goodwill than future other components of comprehensive residual income $\left(\mathrm{x}_{\mathrm{n}}^{\mathrm{a}} \mathrm{x}_{\mathrm{n}}^{*}\right.$ ) (coefficient of 0.41 versus 0.19 in the last two columns). The coefficient carried by the logarithm of the Marketto-Book is very significant and with a consequent value despite the use of the logarithm. The coefficient carried by the P/E median has the expected sign but is not significant at conventional level. However, the wald test increases with the addition of this variable in the regression.

Table 2: FGLS regressions on the Relation between Goodwill and Residual Income One-tailed test. $x_{n+1}^{*}:$ Residual net income $e_{n+1} ; x_{n+1}^{a}:$ Residual comprehensive income ${ }_{n+1}$; InM/B: Natural log of Market to Book ratio; P/E ${ }_{n}$ med: Median Price-Earnings ratio ${ }_{n}$.

\begin{tabular}{|c|c|c|c|c|c|}
\hline $\begin{array}{l}\text { Dependent Variable : Good- } \\
\text { will }_{\mathrm{n}}\end{array}$ & Expected Sign & Coefficient (P Value) & Coefficient (P Value) & Coefficient (P Value) & Coefficient (P Value) \\
\hline \multirow{2}{*}{$\mathbf{x}_{n+1}^{*}$} & \multirow{2}{*}{+} & 0.41 & 0.63 & 0.44 & 0.41 \\
\hline & & 0 & 0 & -0.003 & -0.006 \\
\hline \multirow{2}{*}{$\mathbf{x}^{\mathrm{a}}{ }_{\mathrm{n}+1} \cdot \mathbf{x}_{\mathrm{n}+1}^{*}$} & \multirow{2}{*}{+} & & 0.1 & 0.19 & 0.19 \\
\hline & & & -0.047 & 0 & 0 \\
\hline \multirow{2}{*}{ Ln M/B } & \multirow{2}{*}{+} & & & 0.052 & 0.06 \\
\hline & & & & -0.04 & -0.002 \\
\hline \multirow{2}{*}{$P / E_{n}$ med } & \multirow{5}{*}{+} & & & & 0.005 \\
\hline & & & & & -0.12 \\
\hline \multirow{2}{*}{ Intercept } & & 0.66 & 0.66 & 0.65 & 0.56 \\
\hline & & 0 & 0 & 0 & 0 \\
\hline Wald Test & & 13.05 & 27.4 & 46.1 & 47.4 \\
\hline$P$ value & & 0 & 0 & 0 & 0 \\
\hline
\end{tabular}

Residual income arises not only from acquired goodwill but also internally generated goodwill. Therefore, as a second specification, we replace goodwill by total intangible assets as the dependent variable. The coefficient on the variable $x_{n}^{a}-x_{n}^{*}$ is negative and of low or no significance, whereas the coefficient on $\mathrm{x}_{\mathrm{n}}^{*}$ is positive and significant. It is not surprising since there is no connection between marks or patents capitalized on the balance sheet and the unrealized gains on investment securities or foreign currency translation adjustments; components of OCI.

\section{Conclusion}

We formalized, from the Ohlson RIV model, a theoretical link between acquired goodwill of listed companies and their subsequent residual income; by breaking down the purchase price and goodwill acquired as Johnson \& Petrone [1]. Empirical test of this relation was intended to test three estimators of future earnings:

a) The residual comprehensive income,

b) Broken down into residual income and

c) Additional residual income and the ratio of market-to-book.
Results are the following. First, the relationship between the acquired goodwill and subsequent residual income is very strong, on the net income component, which variations appear as the key to judge the quality of the acquisitions. Second, the residual net income component carries positive coefficients and higher than the additional component (other comprehensive income - OCI) Third, coefficients carried by OCI component are significant and approaching half the value of the coefficients of residual earnings, reflecting the interest of that information for assessing external growth; it is the main contribution of this article, i.e. showing the benefits of reporting OCI. Finally, acquired goodwill and Marketto-Book ratio are positively and highly associated, suggesting that the accounting measure of acquired goodwill is informative for the market.

The original contributions of this research can be summarized as follows:

a) To our knowledge, this is the first study to gather the Residual Income Valuation and the analytical breakdown of acquired goodwill, to formalize a link between the latter and the consecutive residual incomes of the transaction for the purchaser; 
b) Consequently, it is also the first study to empirically estimate this link, taking as estimator the residual income of the purchaser;

The breakdown into two segments, net residual income and additional residual income, highlights some usefulness of OCIs (Other Comprehensive Income), which appear posteriori statistically associated with acquired goodwill, thus as having participated in the formation of transaction prices.

\section{References}

1. Johnson, T, Petrone K (1998) Is Goodwill an Asset? Accounting Horizons 12(3): 178-204.

2. Feltham G, Ohlson J (1995) Valuation and Clean Surplus Accounting for Operating and Financial Activities. Contemporary Accounting Research 11(2): 689-731.

3. Henning, S, Lewis B, Shaw W (2000) Valuation of the Components of Purchased Goodwill. Journal of Accounting Research 38(2): 375-386.
4. Preinreich G (1936) The Fair Value and Yield of Common Stock. The Accounting Review 11(3): 273-289.

5. Ohlson J (1995) Earnings, Book Values and Dividends in Equity Valuation. Contemporary Accounting Research 11(2): 661-687.

6. Ohlson J (1999) On Transitory Earnings. Review of Accounting Studies 4(3): 145-162.

7. Ohlson J (2005) On Accounting Based Valuation Formulae. Review of Accounting Studies 10(2-3): 323-347.

8. Casta JF, Escaffre L, Ramond O (2007) Investissement immatériel et utilité de l'information comptable étude empirique sur les marchés financiers européens. Congrès de l'AFC, Poitiers, France.

9. Cazavan Jeny, A (2004) La relation market-to-book et la reconnaissance des immatériels - une étude du marché français. Comptabilité Contrôle - Audit 10(2): 99-124.

10. Gu F, Lev B (2011) Overpriced Shares, Ill-Advised Acquisitions and Goodwill Impairment. The Accounting Review 88(6): 1995-2022.

\begin{tabular}{|l|}
\hline \multicolumn{1}{|c|}{ Your next submission with Juniper Publishers } \\
will reach you the below assets \\
- Quality Editorial service \\
- Swift Peer Review \\
- Reprints availability \\
- E-prints Service \\
- Manuscript Podcast for convenient understanding \\
- Global attainment for your research \\
- Manuscript accessibility in different formats \\
( Pdf, E-pub, Full Text, Audio) \\
- Unceasing customer service \\
Track the below URL for one-step submission \\
https://juniperpublishers.com/online-submission.php
\end{tabular}

